례

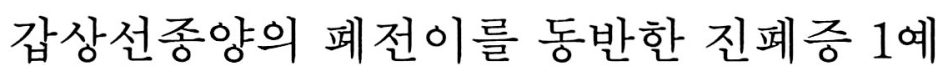

가톨릭대학 의학부 성모병원 직업병과

김경아·임현우·임 영·윤임중

$=$ Abstract $=$

\title{
A Case of Pulmonary Metastasis of Thyroid Cancer with Pneumoconiosis
}

\author{
Kyung Ah Kim, M.D., Hyeon Woo Yim, M.D., Young Lim, M.D. and Im Goung Yun, M.D. \\ Department of Occupational Disease, Catholic University Medical College, Seoul, Korea
}

Pneumoconiosis which is the interstitial lung disease resulting from the chronic inhalation of an respirable dust is the most common occupational disease in Korea. In preventing of disability due to pneumoconiosis, special medical program is excuted routine interval. We have to differentiate pneumoconiosis from miliary tuberculosis, metastatic cancer, sarcoidosis, hemosiderosis, lymphoma, histiocytosis-X, histoplasmosis, viral pneumonia, and so on.

This 52-year-old male patient was admitted to the St. Mary's Hospital due to chest tightness for 1 year. He had experienced pulmonary tuberculosis 30 years ago and operation due to thyroid mass 2 years ago. Chest radiographs showed multiple nodules of $r$-type that were mainly distributed in the hilar regions and the middle lobes. We could diagnose this as pulmonary metastasis of thyroid cancer with pneumoconiosis by open lung biopsy.

\section{서 론}

진폐증은 호홉성분진홉입에 의하여 폐에 조직반응이 생긴 상태를 의미하여 우리나라 직업병의 $70 \%$ 이상을 차지한다 ${ }^{1)}$. 진폐증의 발생에는 분진의 종류, 농도, 입 자크기, 폭로기간, 작업강도, 연령, 개인차 등 여러 가 지 요인들이 관여하나 다량의 불용성 또는 난용성 분진 입자가 폐조직에 장기간 잔축하면 진폐성 변화를 유발하 는 것으로 알려져 있다 ${ }^{21}$. 진폐증은 일반적으로 분진폭 로 경력과 흥부 X-선 소견에 의하여 진단되며 비교적 특 징적인 소견을 보이나 속립성 폐결핵, 전이성 폐종양, 간질성 폐염, 또는 다른 폐 실질에 결절을 일으키는 기 타질 환들과 감별되어야 한다.

저자들은 최근 가톨릭 의대 성모병원 결핵과에 입원하 였던 용접공 52 세 남자 환자에서 갑상선 종양이 폐에 전 이된 것을 경험하였기에 문헌 고찰과 함께 보고하는 바
이다.

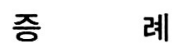

환 자 : 강ㅇ원, 42 세, 남자.

주 소: 1년간 홍부 불쾌감.

직업력 : 과거 25 년간 조선소와 건설회사에서 용접, 배관, 절단 작업종사.

현병력 : 본 환자는 조선소에 근무한 직업력이 있는 바, 진폐증에 대한 정밀진단 위하여 1988년 12월 본원에 입원하였으나 신체검사상 진폐증과 동반된 폐종양이 의 심되어 정밀검사를 시행하였다.

과거력 : 30 년전 폐결핵으로 2 년간 치료 받은 바 있 고, 8년전 (1981년 12월) 지방의 모 병원에서 갑상선 종 괴로 절제수술을 받은 바 있으며 조직 검사상 만성 갑상 선염 (chronic nonspecific thyroiditis)으로 진단되었 다. 약 6 개월 후 홍부 방사선 촬영상 폐혈관을 따라 다발 
성의 결절상 음영이 양 폐야에서 관찰되어 위 의료기관 에서 다시 갑상선 조직검사를 시행하였고 그 결과 선양 갑상선종 (Adenomatous goiter)으로 진단되었다.

가족력 : 특이 사항 없었음.

이학적 소견 : 입원 당시 혈압 $130 / 80 \mathrm{mmHg}$, 맥박수 72 회/분, 호흡수 20 회/분, 체온 $36.5^{\circ} \mathrm{C}$ 였다. 외관상 특 이 소견은 없었으며 결막은 창백하지 않았고, 공막에 황 달은 없었다. 경부에 종괴나 임파절은 촉지되지 않았고, 수술 상흔만이 보였다. 훙부 청진상 호흡음이나 심음에 이상소견은 들리지 않았으며 복부에서 간이나 비장은 촉 지되지 않았다.

검사 소견 : 입원 당시 말초 혈액 검사상 혈색소량 $15.2 \mathrm{~g} / \mathrm{dl}$, 혈구 용적 $45.9 \%$, 백혈구 $5,700 / \mathrm{mm}^{3}$, 혈 소판 $320,000 / \mathrm{mm}^{3}$ 이었으며, 혈청 전해질 및 생화학 검 사는 모두 정상 범위였다. 객담 항산균 도말 검사는 음 성이었으며 객담 균배양검사상 병원성균은 검출되지 않 았다. 입원 3 병일째 시행한 기관지경 검사상 기관지내 종괴나 그외 이상 소견은 보이지 않았으며, 기관지경 세 척을 이용한 항산균 도말검사, 세포진 검사와 균배양 검 사등은 모두 음성이었다. 폐관류 씬티그램 (lung perfusion scintigram) 상에는 양측 폐에 다발성의 작은 관 류 이상과 함께 결절상이 보였다. 입원 7병일째 정확한

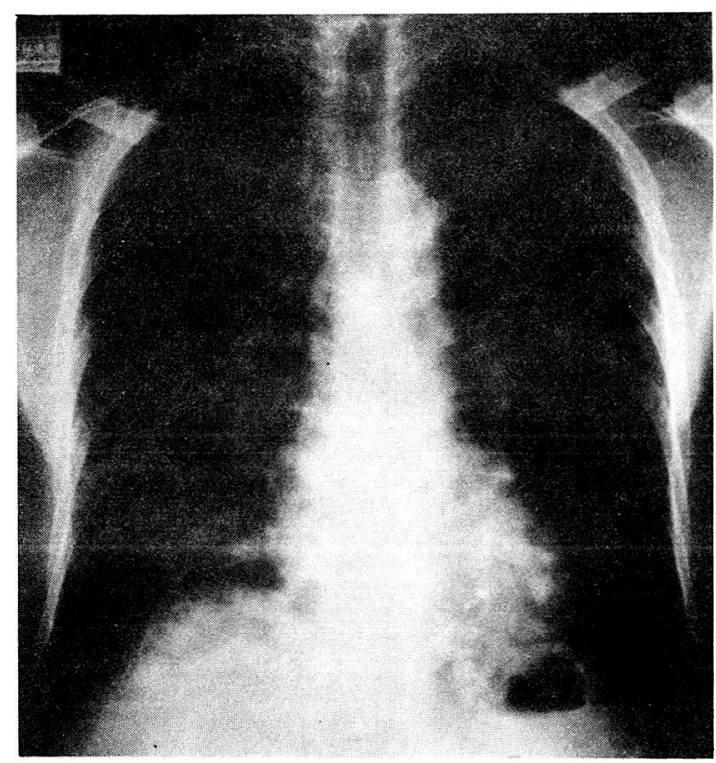

Fig. 1. Chest X-ray (1987.7).

Multiple nodular shadows were seen through out both lung fields.
진단 및 치료를 위해 개훙 생검을 실시하였다.

병리 조직 소견 : 광학 현미경 소견상 정상 폐조직 내

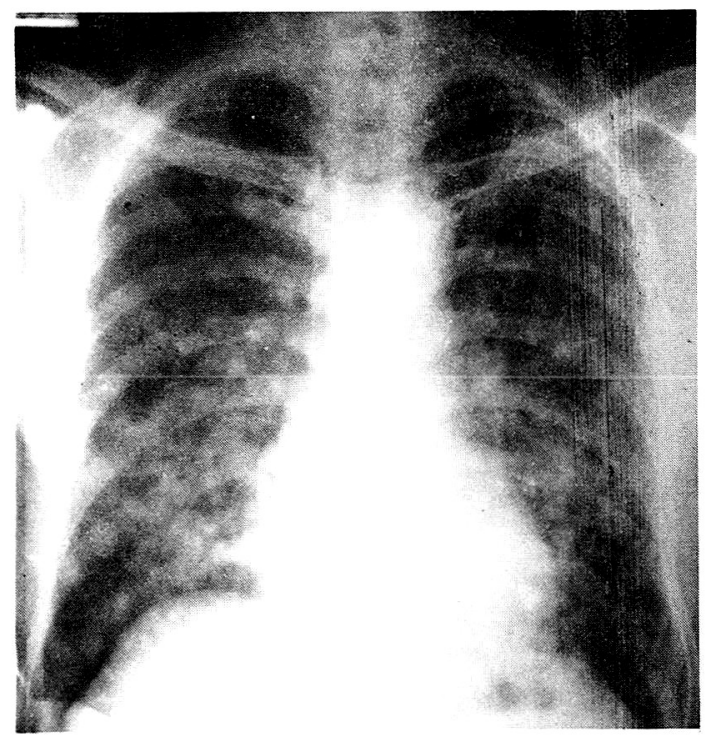

Fig. 2. Chest X-ray (1988.2).

Compared to the chest film of Fig. 1., there is slight aggrevation of multiple nodular shadows.

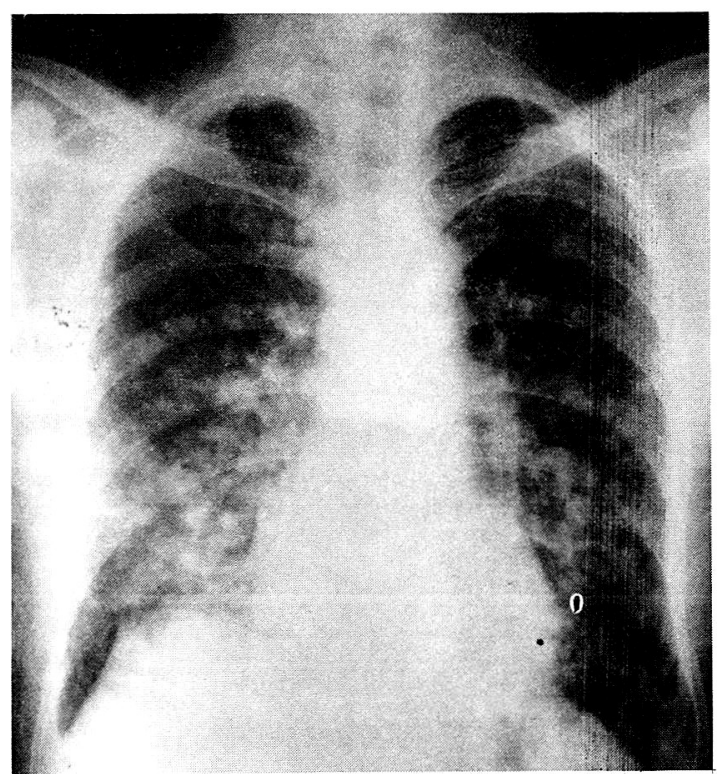

Fig. 3. Chest X-ray (1989.1).

On admission (our hospital): Compared to the chest film of Fig. 2., there is not remarkable interval change. 


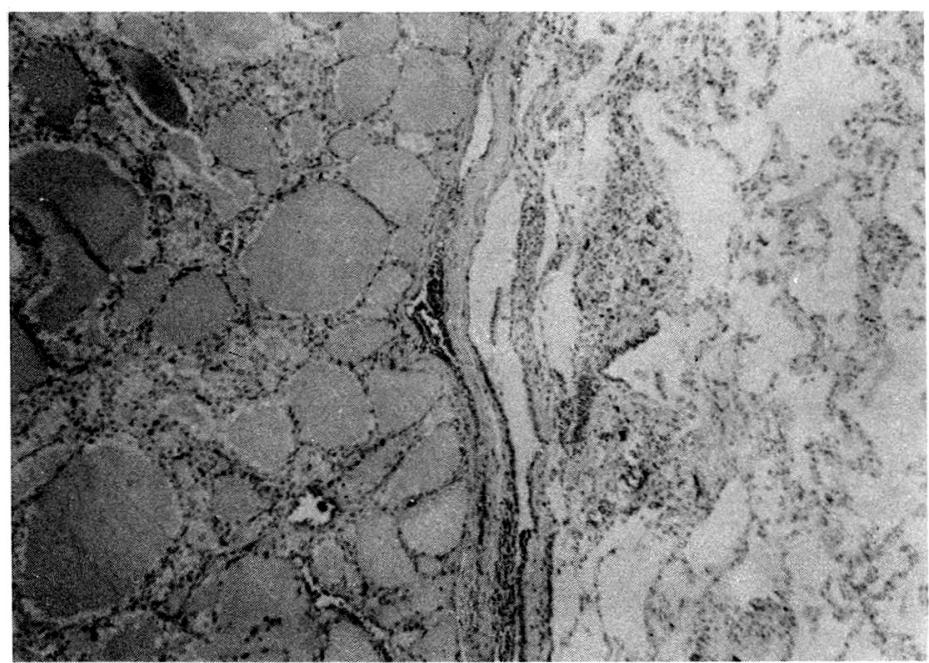

Fig.4-A. Microscopic finiding of biopsy specimen: Showing lung tissue contained thyroid tissue in lung biopsy specimen $(\mathrm{H} \& \mathrm{E}, \times$ $100)$.

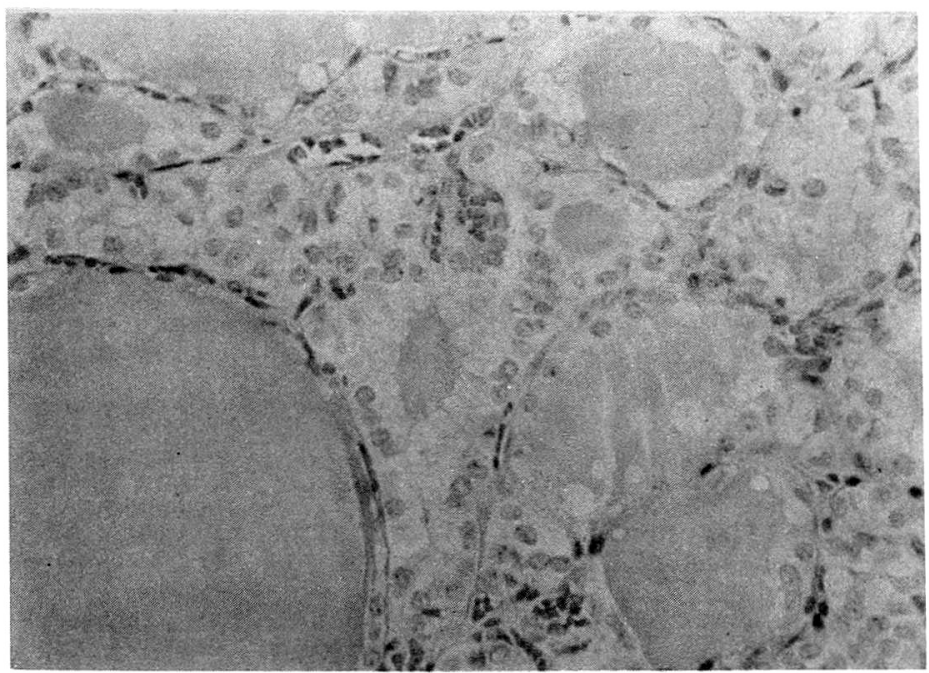

Fig. 4-B. Showing thyroid tissue on biopsy lung specimen: It seems to be normal thyroid tissue except nuclear atypism and mitosis $(\mathrm{H} \& \mathrm{E}, \times 400)$.

에 정상 갑상선 조직과 유사한 조직이 관찰되었다. 고배 율 소견에서 갑상선 조직들은 잘 분화된 세포들에 의해 선 (gland)을 이루고 있었으며, 국소적으로 비정형 세포 들과 이상적으로 큰핵을 가진 세포들로 구성되어 있었고 잘 분화된 소포 형성 갑상선 악성 종양(well differentiated-follicle forming thyroid carcinoma)의 폐 전이 (lung metastasis) 소견을 보였다.
고 안

진폐증은 우리나라의 대표적인 직업성 질환으로 그 대 부분이 탄광부 진폐증이지만 최근 제조업체 근로자에서 발생하는 진폐증에 대한 관심이 높아지고 있으며 국내에 서도 수 차례 보고된 바 있다. 이는 그 나라의 공업의 역 
사와 산업의 발달을 반영하는 것이며 추후 우리나라에서 도 제조업 근로자에서 진폐증 발생이 점차 증가될 것으 로 예측된다.

용접공 진폐증은 1936년 Doig와 Mclaughlim에 의해 최초로 보고된 바 있으며 이들은 호홉기 증상을 동반치 않은 양성 진폐증 (Benign Penumoconiosis)으로 분진 폭로가 중지된후에는 비정상 소견이 없어지거나 감소되 었다고 기술하였다 ${ }^{3,4)}$. 그러나 최근에는 용접 기술의 발 달과 더불어 용접용 금속 종류 및 용접봉도 다양해지고, 용접시 발생하는 홈이 유독가스와 유해 중금속을 복합적 으로 포함하게 되어 이로 인한 폐의 섬유화가 초래될 수 있어 결코 양성 질환으로 분류될 수 없다는 보고가 있 다 ${ }^{5 \text { 8) }}$. 또한 본 예와 같은 조선업 용접공들은 타분야 용 접공들에 비해 선박수리 및 건조시 밀폐된 공간에서 용 접 작업이 이루어지므로 기중 훔 농도가 높고 질병 발생 위험성도 높은 것으로 알려져 있으며9) 1986년 국내에서 의 조선소 용접공들에 대한 진폐증 유병률 조사에서 $8.9 \%$ 로 비교적 높게 나타난 바 있다 ${ }^{10)}$.

용접공 진폐증 음영의 모양과 크기별 분포를 살펴보면 $\mathrm{p}$ 형 $(71.4 \%)$ 이 대부분이고 일부분이 $\mathrm{q}$ 형 $(26.6 \%)$ 이며, $\mathrm{r}$ 형은 관찰되지 않았던 경우와10) 또 다른 보고에 의하면 $\mathrm{p}$ 형 $58.5 \%, \mathrm{q}$ 형 $39.0 \%$, 그리고 $\mathrm{r}$ 형은 $2.5 \%{ }^{11}$ 로 유사 하게 $\mathrm{p}$ 형과 $\mathrm{q}$ 형이 대부분을 차지하는 것으로 되어 있으 나, 본 예에서는 주로 $\mathrm{r}$ 형에 해당하는 결절성 음영이 관 찰되었으며 특히 그 분포가 폐문을 중심으로한 양폐야의 중엽에 나타난 바 이런 경우 진폐증과 감별을 요하는 결 절성 음영을 나타내는 질환중 폐의 전이암과의 감별이 필요하였다.

용접공 진폐증은 폐 섬유화 발생 이전, 대개의 경우 작업 중단시 결절성 음영의 감소를 나타내고 호홉곤란, 홍통, 객담, 기침 등의 임상 증상은 매우 드물며 훙부사 진 추적검사상 감염등의 합병증이 없는 한 진행이 느린 특징을 가지고 있다. 최근 널리 이용되는 기관지 폐포 세척술을 통한 폐포강내의 세포분석, 폐조직 생검시 ferruginous body의 유무로서도 진단이 가능해졌으며 전자현미경을 통한 mineral analysis를 이용하여 진폐 증의 종류를 알 수도 있게 되었다.

본 예에서와 같은 갑상성 악성 종양의 폐전이 빈도는 가장 낮은 경우 2 5\% ${ }^{12 ~ 15)}$ 부터 $20 \%{ }^{16)}$ 까지 보고되어 그 차이가 크며 특별한 치료 없이도 매우 느린 경로를 밟 는 것이 보통이나 ${ }^{17)}$ 그럼에도 불구하고 폐에 전이된 환
자의 사망율은 10 년 생존율이 $20 \%$ 로 보고된 바 있다 ${ }^{18)}$.

모든 갑상선 악성 종양의 기원은 상피조직으로서 크게 여포 상피(follicular epithelium)에서 유래한 유두상 상피 암 (papillary carcinoma), 여포상 상 피암(follicular carcinoma) 과, 비정형 상피암 (anaplastic carcinoma) 그리고 드물지만 여포 주위세포 (parafollicular cell: c-cell)에서 유래한 medullary carcinoma 의 2 가지 형으로 나눌 수 있으며 ${ }^{19)}$ 이중 유두상 상피암 이 약 $2 / 3$ 를 차지하고 40 세 이하에서는 전체 갑상선 악 성 종양의 $80 \%$ 를 차지하지만, 그 예후는 매우 좋은 것 으로 보고 되어있다. 유두상 상피암의 경우 국소 임파절 로 전이가 약 $50 \%^{12,21,22)}$ 이나 임파절 전이가 나쁜 예후 를 나타내는 것은 아니며 오히려 어떤 보고에 의하면 임 파절 전이가 증가됨에 따라 그 예후가 더 좋다는 보고가 있다 ${ }^{12,22)}$.

여포상 상피암은 모든 갑상선 악성 종양의 약 $15 \%$ 를 차지하며 대개 40 대 이후에 호발하고, 여자가 남자에 비 해 그 유병율이 2 3배 정도 높다. 유두상 상피암보다 그 악성의 정도는 더 심하며 국소 임파절로의 파급은 적 으나 혈성전파를 거쳐 골격, 폐, 간장으로 비교적 조기 에 전파되어 고령화에 따라 점차 악성화된다 ${ }^{19,23)}$. 여포 상 상피암 (follicular carcinoma)은 그 크기가 다양하 고 협막(capsule)으로 둘러싸여 있으며 여포상 선종 (follicular adenoma) 과의 구별은 조직학적으로 가능 하다. 조직학적으로 여포상 상피암의 진단은 헙막의 침 범 (invasion)과 또는 혈관의 침범이 증명되는데 기초를 두며 부위에 따라 어떤 부위는 거의 정상과 비슷하여 여 포의 크기가 더 작고 colloid를 더 적게 포함하는데 비 해, 다른 부위는 세포의 solid sheet를 형 성하여 분화 정 도의 불규칙성을 보이는데 이를 Hürthle cello이라 한 다 ${ }^{19)}$. 여포상 상피암은 주위 조직 침범 부위에 따라 예 후가 정해지면 이때 전이된 조직이 정상 갑상선 조직과 유사한 양상을 띄고 있을 수도 있다.

임상 증상은 매우 다양하여 어떤 경우에는 수년간 goiter로 남아 있는 경우도 있고 통증과 주위구조 침범 은 보통 말기에 나타나 흔히 골파급에 따른 병적 골절과 폐의 전이결절을 보이게 된다 ${ }^{19}$.

방사선 검사와 scanning으로 추적 검사를 하게 되면 micronodular와 macrondular한 음영들이 보이면 주로 폐하부나 전폐야에 걸쳐 reticular pattern으로 변화하 는데 $0.5 \sim 3 \mathrm{~cm}$ 직경의 결절성 음영들이 대부분이다 ${ }^{24)}$. 


\section{결 론}

본 예는 건설회사 및 조선소에서 배관, 절단 그리고 용접 작업등에 25 년간 종사한 일이 있고 홍부 $\mathrm{X}$-선 소 견상 r형의 결절성 음영들이 관찰되어 우선적으로 용접 공 진폐증을 의심케 하였고 두번에 걸친 갑상선의 조직 생검상 악성종양의 소견을 보이지 않아 진폐증과의 감별 이 어려웠으나 개흥 생검으로 전이성 갑상선 종양이 밝 혀진 예이다.

저자들은 장기간 분진 작업에 종사하였던 환자에서 폐 전이로 인하여 전이성 갑상선 악성 종양이 밝혀진 1예를 경험하였기에 문헌 고찰과 함께 이를 보고하는 바이다.

\section{REFERENCES}

1) 대한산업보건협희 : 특수건강진단 종합연보, 서울, 대 한산업보건협회, 1988

2) 윤임중 : 한국 탄광부들에 있어서의 진폐증의 유병률. 결핵 및 호흡기 질환 24(1):1-10, 1977

3) Rom WN: Environmental and Occupational Medicine. Boston, Little Brown and Company, 1983

4) Zenz C: Occupational Med 2nd Ed. Chicago. London. Boca Raton, Year Book Medical Publishers INC, 1988

5) Charr R: Respiratory Disorders among Welders. Am Rev Tuberc and Pulm Dis 71:877, 1955

6) Angervall L, Hasson G, Rockert H: Pulmonary Siderosis in Electrical Welders. Acta Pathol Microbiol Scad 49:373, 1960

7) Meyer EC, Kratzinger SF, Miller WH: Pulmonary Fibrosis in an Arc Welder. Arch Environ Health 15: 462-469, 1967

8) Guidotti TL, Denee PB, Abraham JL: Arc Welders' Pneumoconiosis: Application of advanced Scanning Electron Microscopy. Arch Environ Health 33: 119-124, 1978

9) Stern RM: Assesment of Risk of Lung Cancer for Welders. Arch of Environ Health 38:148-155, 1983

10) 이채언, 이종태, 손해숙 : 부산 지역 조선업 용접공들 의 진폐증에 관한 역학적 조사 연구. 예방의학학회지 22:153-161, 1989
11) 윤임중 등 : 용접공 진폐증의 검사 소견. 한국의 산업 의 학 21(3):64-72, 1982

12) Mazzaferri EL, Young RL, Oretel JE, Kemmerer WT, Page CP: Papillary Thyroid Carcinoma: The Impact of Therapy in 570 Patients. Medicine 56:171 $-196,1977$

13) Young RL, Mazzaferri EL, Rahe AJ, Dorfman SG: Pure Follicular Thyroid Carcinoma. Impact of Therapy in 214 Patients. J Nucl Med 21:733-737, 1980

14) Setak, Takahash S: Thyroid Carcinoma. In Surgery 61:541-546, 1976

15) Woolner LB, Beahrs OH, Black BM, McConahey WM, Keating FR: Classification and Prognosis of Thyroid Carcinoma Study of 885 Cases. Am J Sug 102:354-387, 1961

16) Franssila KO: Value of Histologic Classification Thyroid Cancer. Acta Pathol Microbiol Scand 225: 5,1971

17) Kressel H, Gamsu G, Kalifa LG, Webb WR: Prolonged Growth Arrest of Pulmonary Metasatais in Papillary Thyroid Carcinoma. West J Med 129:424421, 1978

18) Nemec J, Zamarazil V, Pohunkova D, Rohling S: Radio-iodine Treatment of Pulmonary Metastasis of Differentiated Thyroid Cancer. Nucklearmedizin 18:86-96, 1976

19) Robert H, Wiliam S: Text Book of Endocrinology 6th Ed. Philadelphia, London, Tronto, Tokyo, W.B. Saunders Compay, 1981

20) Robert DL: Thyroid Cancer. Medical Clinics of North America 65(5):1079-1096, 1985

21) Cady B, Sedwich CE, Meissner WA: Changing Clinical, Pathological, Therapeutic and Survival Patterns in the Management of Papillary Thyroid Can. cinoma. Ann Surg 183:541, 1976

22) Hutter RVP, Frazell EW, Foote FW: Elective Radical Neck Dissection. Cancer 20:87, 1970

23) Davis JC, Hipkin W: Clinical Endocrine Pathology. Oxford, London, Edinburgh, Melbourine: Blackwell Scientific Publication, 1977

24) Jean PM, Jean CS, Henri G, Gerard G, Francoise AK, Francosis B: Pulmonary Metastases in Differntiated Thyroid Carcinoma. Cancer 53:982-992, 1984 